\title{
An Analysis of the Learning Behavior of Cultural and Creative Industries Employing Structural Equation Modeling
}

\author{
Wei-Shang Fan, Kuo-Chung Huang, and Ko-Chia Hsu
}

\begin{abstract}
Occupational training is a term has long been an important directive for government administration, because it is necessary to have better understanding of the various factors influencing Trainee learning behavior in occupational training, and Promote enterprises to pay attention to the development of human capital,Invest in improving the quality of workers. This research uses(TAM) and (TPB) two theories and Structure Equation Modeling (SEM). to learners who participated in the laborer autonomy learning project and aborigine specialized occupational training course held by the Tainan Training Center, Bureau of Employment and Vocational Training. A total of $\mathbf{3 0 0}$ questionnaires were released. After eliminating 17 invalid samples that were filled out incompletely, there were sample 283 valid questionnaires. The research results showed that: (1) perceived usefulness and perceived ease of use have a significant positive influence on the Attitude of participating learners; (2) perceived usefulness and perceived ease of use have a significant positive influence on the training intention of participating learners; (3) Perceived usefulness and perceived ease of use have no significant direct positive impact on the learning behavior of participating learners; (4) Perceived usefulness and perceived ease of use have a complete mediating effect on learning behaviors of participating learners through attitudes and training intentions.
\end{abstract}

Index Terms-Occupational training, theory of planned behavior, technology acceptance model.

\section{INTRODUCTION}

Faced with the advent of globalization and the advent of a knowledge-based economy, industrial structure and technology are rapidly changing. Occupational training has now become the primary task to enhance the competitiveness and training programs for talented people. However, determining how to strengthen the integration of training resources and construction training networks to actively promote the career development of workers and planning the training of the unemployed and unemployed persons in pre-employment, transfer or secondary expertise to upgrade their employment skills to return to the labor market as soon as possible has become the focus of the development of vocational training programs. This study has several purposes (1) According to the theory of TPB and TAM, it is determined that cognitive usefulness and usability have an impact on

Manuscript received January 9, 2018; revised May 1, 2018.

Wei-Shang Fan and Kuo-Chung Huang are with Rice Department of Business Administration, Nanhua University, Taiwan (e-mail: ws.fan@msa.hinet.net, kchuang@mail.nhu.edu.tw).

Ko-Chia Hsu is with Department of Business Administration, Nanhua University, Taiwan (e-mail: chia361268@gmail.com). training attitude and Training intent to participate; (2) Using TAM since, learning behavior influences TAM through attitude and willingness to participate.

\section{LITERATURE DISCUSSION AND RESEARCH FRAMEWORK}

\section{A. Cultural and Creative Industries}

The traditional special industry of cultural and creative industries started its cultivation in early (1957) when the government faced a huge deficit in the international balance of payments in Taiwan and adopted a strategy of "building agriculture by agriculture and developing Taiwan by industry" as its national construction strategy.

In (1954), the establishment of "Nantou County Craft Research Class" was changed to "Nantou County Craft Institute" as the basis for the overseas demand of Taiwan's cultural and creative industries. (2010) National Taiwan Institute of Technology changed to "National Taiwan Technology Research and Development Center" for the future handicrafts industry has established an important position.

The cultural and creative industry creates wealth and employment opportunities and promotes national aesthetic quality to improve the atmosphere of civic life. The industry originated from an accumulation of creativity and culture that was shaped and exerted by intellectual property.

\section{B. Program Behavior Theory (TPB)}

The Planned Behavior Theory is Ajzen's [1] extensionist revision theory based on the Theory of Reasoned Action (TRA) [2], and exhibits better performance at the behavioral level.

The most significant model for the current study is Ajzen's [3] Theory of Planned Behavior (TPB), which attempts to explain the causal link between values, beliefs, attitudes, intentions and behavior. In simple terms, the theory proposes that when given a behavioral choice, an individual will consider the alternatives and assesses their consequences based on their beliefs relating to the actions and their effects. These beliefs determine an individual's attitudes regarding the possible actions, which in turn influence the intention to act with behavioral intention being a strong indicator of the actual behavior chosen [3].

The main difference between TPB and TRA is that TPB posits that not all human behavioral decisions are fully controlled by individual will, and in reality the control of individual will over behavioral decisions is incomplete. TPB thus adds a decision factor that is so-called perceived behavior control (PBC). 


\section{Technology Accepts Model Theory (TAM)}

The theoretical basis for the "science and technology acceptance model" comes from the Theory of Reasoned Action (TRA) theory of rational behavior As shown in Figure 1. TRA theory asserts that users' beliefs affect their attitudes and form a behavioral intention that affects the final result. TAM was proposed by Dr. Davis in his dissertation. The main purpose of TAM is to provide a general explanation mode for end users and technical computing users to explain the determinants of user acceptance of computer information systems. Based on the structure of "Theory of Reasoned Action" (TRA), Davis [4] discarded the belief and motivation of subjective norms and norms in TRA theory, and then adjusted the relationship between the original variables to some extent, and used it to explain User acceptance of information technology.

The technology acceptance model (TAM) is an information system model used to evaluate why individuals accept and use a new information system or technology [5]. It posits that two particular beliefs that perceived ease of use (PEU) and perceived usefulness (PU) are of primary relevance, and behavior intention (BI) is a function of PU and PEU that directly influences the actual usage behavior of users. PEU is the degree to which the prospective user perceives the information system easy to use. PU is defined as the subjective belief that the use of a given information system improves users' working efficiency.

Perceived usefulness is defined as the degree to which a person believes that using a particular system would enhance his/her job performance. Perceived usefulness originally refers to job-related productivity, performance, and effectiveness [4]. Perceived usefulness complies with the explanation for near-term consequence given by Triandis [6] and Thompson [7], [8]. Davis [9] described a high Perceived Usefulness as one for which a user believed in the existence of a positive user-performance relationship. That is, the user perceives the system to be an effective way of performing the tasks.

Perceived Ease of Use refers to the degree to which a person believes that using a particular system would be free of effort. Given that effort is a finite resource, an application perceived easier to use than another is more likely to be accepted by users [9]. It is one of the major behavioral beliefs that influence user's intention to technology acceptance in both the original and the revised TAM models. Therefore, the easier a user feels a new system can be used, the more positive attitude he will possess to adopt such new system.

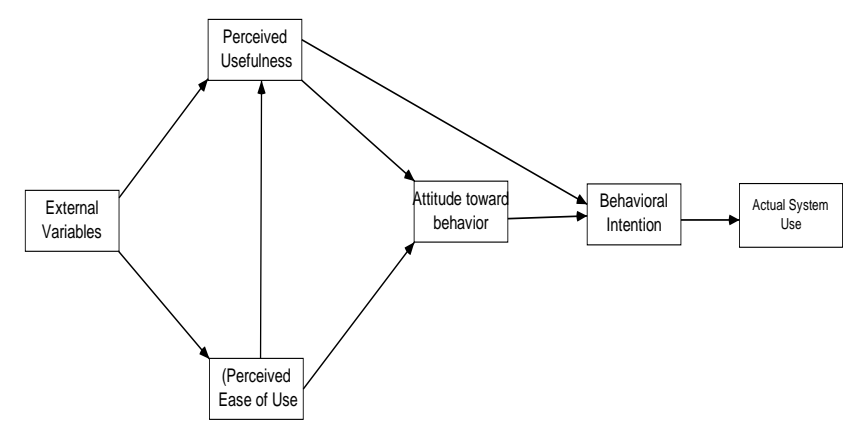

Fig. 1. Science and technology to accept mode architecture source Davis (1989).

\section{Learning Behavior}

Bugelski [10] pointed out that learning is a psychological activity by which individuals acquire knowledge, skills, debt, attitudes and ideals and retain such psychological activity for their application, resulting in continual adjustments and changes in behavior. Schunk [11] learners' observation, evaluation and response after learning affect their self-efficacy and affect the goals of follow-up activities.

Moran [12] argues that learning behavior is a combination of individual learning activities. Yamauchi [13] discussed how technology could help students promote motivation and help teachers provide ways to meet learners' needs.

Oddi [14] further point out that self-directed learning is a personality trait that has an open mind and is receptive to vagueness and change and maintains active learning motivation and ongoing learning.

\section{E. Research Framework}

This study proposes a total of five hypotheses to verify the relevant aspects in practice. The research framework is shown in Fig. 2.

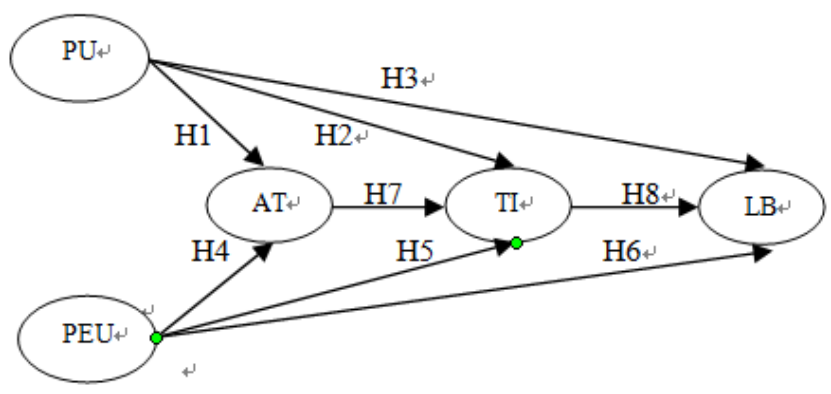

Fig. 2. Research framework.

Davis [4] definition of perceived usefulness is "the user's subjective belief that the use of a particular technology system will have a bearing on his job performance and future." That is, the benefits that his personal perceptions can have on the performance of his present or future workforce when using this new system. Users therefore have a positive attitude towards the system and reinforce its positive opinion of the results of the system. At home and abroad, many scholars and experts have found that most of the TAM models are used in surveys of "user acceptance of information technology" and the results are significantly satisfied. Therefore, this study adopts the TAM model as the framework, To explore whether trainees' learning behaviors in cultural and creative industries can influence their learning behavior through attitude and training intentions. Based on the above literature, this study is based on the following hypothesis:

H1: Perceived Usefulness has a direct impact on Attitude

H2: Perceived Usefulness has a direct impact on Training intent

H3: Perceived Usefulness has a direct impact on Learning behavior

Davis [4] defines perceived ease of use as "the ease with which a user learns to learn to use a particular technology system." That is, how easy it is for the user to learn to become familiar with using a new system. When a user comes into contact with a new system, it often happens that whether the user can accept the new system because of the difficulty in 
operation often increases or decreases the preference of the new system. Therefore, the higher the user's perceived ease of use of the system is. Based on the above literature, this study is based on the following hypothesis:

H4: Perceived Ease of Use has a direct impact on Attitude

H5: Perceived Ease of Use has a direct impact on Training intent

H6: Perceived Ease of Use has a direct impact on Learning behavior

Learning behavior refers to a variety of explicit behavior related to individual participation in learning, internal psychological activity or psychological history, that learning-related behavior can be called learning behavior. Therefore, it is possible to define learning behavior as the attitude and intention of the whole course of students participating in vocational training, including the perception of training courses, the situation of attendance and participation, the attitude, method, intention and motivation of classroom learning:

H7: Attitude has a direct impact on Training intent

H8 : Training intent has a direct impact on Learning behavior.

\section{DATA AND ANALYSIS RESULTS}

\section{A. Trainee Attributes Analysis}

Table I shows that respondents were identified as 197 (69.6\%) non-aboriginal, followed by $86(31.4 \%)$ indigenous aborigines; respondents were $261(92.2 \%)$ females, followed by men with $22(7.8 \%)$, with $144(50.9 \%)$ aged 36 to 50 years old, in addition, $85(30.0 \%)$ were over 51 years old and 54 (19.1\%) were $20-35$ years old. With the highest level of education being 137 (48.4\%), 82 (29.0\%) above junior and junior high schools, 64 (22.6\%) below junior middle schools and junior high schools, 82 (29.0\%). 78 (27.6\%) were unemployed and $41(14.5 \%)$ were employed in business and industry. The marital status was married with 225 (79.5\%) and $58(20.5 \%)$ unmarried; $143(50.5 \%)$ were the most monthly incomes below 20,000 yuan, followed by $86(30.4 \%)$ at 20001-30000 yuan and 54 (19.1\%) above 30,000 yuan, respectively. The number of occupations that participated in arts and crafts was 3; the following $231(81.6 \%)$ were the most, followed by 49 (17.3\%) 4-6 times, followed by 3 (1.1\%) by 7 times.

TABLE I: DESCRIPTIVE STATISTICAL ANALYSIS

\begin{tabular}{lccc}
\hline $\begin{array}{l}\text { Personal attribute } \\
\text { percentage }\end{array}$ & Number of samples & percentage & Cumulative \\
\hline $\begin{array}{l}\text { identity } \\
\text { Aboriginal people }\end{array}$ & 86 & 30.4 & 30.4 \\
Non-Aboriginal & 197 & 69.6 & 100.0 \\
\hline gender & 22 & 7.8 & 7.8 \\
male & 261 & 92.2 & 100.0 \\
female & 54 & 19.1 & 19.1 \\
ag & 144 & 50.9 & 70.0 \\
20-35 year old & 85 & 30.0 & 100.0 \\
36-50 year old & & & \\
51 Above age & 64 & 22.6 & 22.6 \\
\hline Education & 137 & 48.4 & 71.0 \\
In the country (below) & 82 & 29.0 & 100.0 \\
High school job & & & \\
College or above & & & \\
\hline
\end{tabular}

\begin{tabular}{|c|c|c|c|}
\hline \multicolumn{4}{|l|}{ Current employment status } \\
\hline Unemployed & 78 & 27.6 & 27.6 \\
\hline Business Services & 41 & 14.5 & 42.0 \\
\hline manufacturing & 25 & 8.8 & 50.9 \\
\hline Military education & 20 & 7.1 & 58.0 \\
\hline Agriculture related & 23 & 8.1 & 66.1 \\
\hline communications industry & 2 & 0.7 & 66.8 \\
\hline Finance and Insurance & 12 & 4.2 & 71.0 \\
\hline other & 82 & 29.0 & 100.0 \\
\hline \multicolumn{4}{|l|}{ marital status } \\
\hline married & 225 & 79.5 & 79.5 \\
\hline unmarried & 58 & 20.5 & 100.0 \\
\hline \multicolumn{4}{|l|}{ monthly income } \\
\hline 20000 the following & 143 & 50.5 & 50.5 \\
\hline 20001-30000 yuan & 86 & 30.4 & 80.9 \\
\hline 0001 the above & 54 & 19.1 & 100.0 \\
\hline \multicolumn{4}{|c|}{ The number of vocational training } \\
\hline 3Times the following & 231 & 81.6 & 81.6 \\
\hline 4-6 Times & 49 & 17.3 & 98.9 \\
\hline 7 Times or more & 3 & 1.1 & 100.0 \\
\hline
\end{tabular}

Source: This study is organized

\section{B. Confirmatory Factor Analysis}

The fitness of the overall model is mainly to evaluate the degree of fitness between the overall model and the observed data, i.e. the evaluation of external quality of model. According to Hair, Anderson, Tatham and Black [15], the fitness of an overall model is classified into three types: measurement of absolute fitness, measurement of incremental fitness, and measurement of sententious fitness. According to Byrne [16], this study further checks and analyzes the modification index of results (M.I.) to facilitate the discussion and analysis on the modification of the final model. According to the analysis results, the various indices in the overall sample model after modification reached the evaluation criteria, as shown in Table 2.

TABLE II: SCALE CONFIRMATORY FACTOR ANALYSIS RESULTS

\begin{tabular}{cccc}
\hline Test indicators & $\begin{array}{c}\text { Fit standard or } \\
\text { critical value }\end{array}$ & $\begin{array}{c}\text { Test results } \\
\text { data }\end{array}$ & Adapt to judge \\
\hline $\begin{array}{c}\text { Absolute fitness } \\
\text { index }\end{array}$ & & & \\
\hline$\chi^{2}$ & $\mathrm{P}>0.05$ & 0.00 & Yes \\
RMR & $<0.05$ & 0.03 & support \\
RMSEA & $<0.08$ & 0.05 & support \\
GFI & $>0.90$ & 0.91 & support \\
AGFI & $>0.90$ & 0.88 & support
\end{tabular}

Value-added

fitness index

$\begin{array}{llll}\text { NFI } & >0.90 & 0.93 & \text { support }\end{array}$

$\begin{array}{llll}\text { RFI } & >0.90 & 0.91 & \text { support }\end{array}$

$\begin{array}{llll}\text { IFI } & >0.90 & 0.96 & \text { support }\end{array}$

$\begin{array}{llll}\text { CFI } & >0.90 & 0.97 & \text { support }\end{array}$

$\begin{array}{llll}\text { TLI } & >0.90 & 0.96 & \text { support }\end{array}$

\begin{tabular}{cccc} 
Simple fit index & & & \\
PGFI & $>0.50$ & 0.68 & support \\
PNFI $>0.50$ & $>0.50$ & 0.77 & support \\
PCFI $>0.50$ & $>0.50$ & 0.80 & support \\
$\chi^{2}$ & $<5$ & 1.68 & support \\
\hline
\end{tabular}

Source: This study is organized 


\section{Model fit}

Based on the above results, The following table 3 the Perceived Usefulness, Perceived Ease of Use,Attitude, Training intent, and Learning behavior of the five facets are shown in, except for H3: Perceived Usefulness for Learning behavior and H6 Perceived Ease of Use for Learning behavior were not supported. The remaining six routes were all supported.

TABLE III: RESULTS OF RELIABILITY AND CONVERGENT VALIDITY TEST

\begin{tabular}{|c|c|c|c|}
\hline Independent variable & $\begin{array}{l}\text { Direct } \\
\text { effects }\end{array}$ & $\begin{array}{l}\text { Indirect } \\
\text { effe }\end{array}$ & $\begin{array}{l}\text { Total } \\
\text { effects }\end{array}$ \\
\hline Perceived Usefulness $\rightarrow$ Attitude & 0.34 & -- & -- \\
\hline Perceived Ease of Use $\rightarrow$ Attitude & 0.33 & -- & -- \\
\hline $\begin{array}{l}\text { Perceived Usefulness } \rightarrow \text { Training } \\
\text { intent }\end{array}$ & 0.23 & -- & -- \\
\hline $\begin{array}{l}\text { Perceived Ease of Use } \rightarrow \text { Training } \\
\text { intent }\end{array}$ & 0.37 & -- & -- \\
\hline Attitude $\rightarrow$ Training intent & 0.55 & -- & -- \\
\hline $\begin{array}{l}\text { Training intent } \rightarrow \text { Learning } \\
\text { behavior }\end{array}$ & 0.24 & -- & -- \\
\hline $\begin{array}{l}\text { Perceived Usefulness } \rightarrow \text { Attitude } \\
\rightarrow \text { Training intent } \rightarrow \text { Learning } \\
\text { behavior }\end{array}$ & -- & 0.19 & 0.19 \\
\hline $\begin{array}{l}\text { Perceived Usefulness } \rightarrow \text { Training } \\
\text { intent } \rightarrow \text { Learning behavior }\end{array}$ & -- & 0.08 & 0.08 \\
\hline $\begin{array}{l}\text { Perceived Ease of Use } \rightarrow \text { Attitude } \\
\rightarrow \text { Training intent } \rightarrow \text { Learning } \\
\text { behavior }\end{array}$ & -- & 0.13 & 0.13 \\
\hline $\begin{array}{l}\text { Perceived Ease of Use } \rightarrow \text { Training } \\
\text { intent } \rightarrow \text { Learning behavior }\end{array}$ & -- & 0.09 & 0.09 \\
\hline $\begin{array}{l}\text { Perceived Usefulness } \rightarrow \text { Learning } \\
\text { behavior }\end{array}$ & 0 & -- & -- \\
\hline $\begin{array}{l}\text { Perceived Ease of Use } \rightarrow \\
\text { Learning behavior }\end{array}$ & 0 & -- & -- \\
\hline
\end{tabular}

\section{CONCLUSION AND SugGeSTIONS}

In the present study, through the verification and analysis of the path hypothesis, we found that other assumptions have significant effects except for the cognitively useful and cognitive-easy-to-use effects on the two hypotheses of learning behavior. Cognitive positive and negative impact on attitudes and training intention; Cognitive easy-to-use positive impact attitude and training intention; Attitude has a positive impact on training intention; Training intention has a positive effect on learning behavior. In addition, the present study uses a meta-agent validation approach to verify the usefulness of the interventional effects between cognitive and accessible cognitive and attitudes and training intention and learning behavior. About the impact of learning behavior, there is a complete intermediary influence.

In order to enrich the integrity of the research data, the research strives to be rigorous in the development of the architecture and in the design of the research to ensure the objectivity of the research results. However, due to the limited research resources, there are still many research limitations which are still to be improved Where, roughly as follows:

1. Vocational training courses are divided into pre-vocational training, on-the-job training, training with the second specialty, etc., because the Institute of the survey can not cover all the subjects, the proposed future researchers can be eligible to do all the training to do the reorganization and classification, To expand the scope of the study.

2. This study mainly discusses the training satisfaction of creative handicraft training as a research topic. Due to the large number of vocational training types, it is recommended that follow-up researchers consider various types of vocational training as a research consideration, which will help the contractor to provide better training methods and teaching in the vocational training business.

\section{REFERENCES}

[1] I. Ajzen, "From intention to actions: A theory of planned Behavior," J. InKuhl, and J. Beckmann, "Action control: Form cognition to behavior," Berlin Heidelberg Springer Verlag, pp.11-39, 1985.

[2] M. Fishbein, and I. Ajzen, "Belief, Attitude, Intention, and Behavior: An Introduction to Theory and Research, Reading," Addison-Wesley, Massachusetts 1975.

[3] I. Ajzen, "The theory of planned behavior, Organizational," Behaviour and Human Decision Processes, vol. 50, no. 2, pp.179-211, 1991.

[4] F. D. Davis, "Perceived Usefulness, Perceived Ease of Use and User Acceptance of Information Technology," MIS Quarterly, pp.318-340, September, 1989.

[5] N. Park, R. Roman, S. Lee, and J. E. Chung, "User acceptance of a digital library system in developing countries: An application of the technology acceptance model," International Journal of Information Management, vol. 29, pp.196-209, 2009.

[6] H. C. Triandis, "Values, Attitudes and Interpersonal Behavior." in H.E. Howe (Ed.) Nebraska Symposium on Motivation, 1979: Beliefs, Attitudes and Values, Lincoln, Nebraska: University of Nebraska Press, pp.195-259, 1980

[7] R. L. Thompson, C. H. Higgins, and J. M. Howell, "Towards a Conceptual Model of Utilization," MIS Quarterly, vol. 15, no. 1, pp.125-143, 1991.

[8] R. L. Thompson and G. Rose, "Information Technology Adoption and Use," in proceedings, ASAC Annual Conference: Information Systems, vol. 15 , no. 4, pp.16-26, 1994.

[9] F. D. Davis, "Perceived Usefulness, Perceived Ease of Use, and User Acceptance of Information Technology," MIS Quarterly, vol. 13, no. 3, pp.319-340, 1989a.

[10] B. R. Bugelski, The psvchologv of learning. New York: Holt, Rinehart and Winston, Inc. 1956.

[11] D. H. Schunk, "Self-regulation of self-efficacy and attributions in academic settings," In D. H., Schunk \& B. J. Zimmerman (Eds.), Self-regulation of learning and performance (pp.75-100). Hillsdale, NJ: Lawrence Erlbaum associates. 1994.

[12] J. J. Moran, Assessing Adult Learning - A Guide for Practitioners. Malabar, Florida: Krieger Puboishing Co. 1997.

[13] M. Yamauchi, "Integrating internet technology into the EFL classroom: A case study," International Journal of Pedagogies and learning. vol. 5, no. 2, pp.3-19, 2009.

[14] L. F. Oddi, "Development and validation of an instrument to identify self-directed continuing learners," Adult Education Quarterly, vol. 36, no. 2, pp. 97-107, 1986.

[15] J. F. Hair, R. E. Anderson, R. L. Taltam, and W. C. Black, "Multivariate Data Analysis with Readings," 5th ed. Prentice-Hall, New York, 1998.

[16] Byrne, B. M.(2001).Structural equation modeling with AMOS: Basic concepts, applications, and programming.New Jersey, NJ:Lawrence Erlbaum.

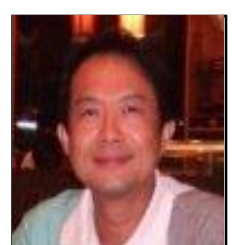

Wei-Shang Fan was born in Chiayi, Taiwan 1960's he holds his Ph.D. in business management from National Chung Cheng University . His main research includes marketing management, strategic marketing, international business management and entrepreneurship management.

His publications:

(1) The Research of ERP Implications in Mongolian Companies Market Analysis, Journal of Tourism and Leisure Management, 3,2,pp108-117,2015.

(2) Using Importance-Performance Analysis in Evaluating Taiwan Blog e-Service Quality, Journal oEconomics, Business and Management,pp 338-345,2015.

(3) 2012, Exploring the Choice Behavior on the Retailing Delivery Provider for Online Auction Consumers, International Journal of Electronic 
Commerce Studies,3,2,pp325-334, 2012

(4).Effect of Service Value and Switching Cost on Customers Loyalty:A Case Study of TV Shopping in Taiwan, Pakistan Journal of Statistics,

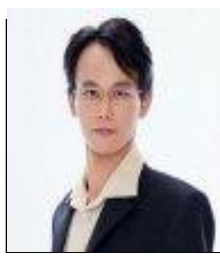

Kuo-Chung Huang was born in Taipei, Taiwan, 1972's is a professor of Department of Business Administration in Nanhua University in Taiwan. He received a $\mathrm{PhD}$ degree from the Graduate Institute of Management Sciences at Tamkang University, Taiwan. His research interests focus on the fields of sampling methods, statistical analysis and mathematical modeling. He has published many international journal papers regarding the above-mentioned fields
Ko-Chia Hsu was born in Chiayi, Taiwan in 1979's he holds the highest academic qualification and master degree in business administration from Nanhua University in Taiwan. His main research areas include marketing management, business management, culture and creative industries. Now Nanhua University Department of Business Administration doctoral student 